\title{
INFLUENCE OF DIFFERENT LIGHTING SPECTRA ON GROWTH AND DEVELOPMENT OF IN VITRO VIRUS-FREE POTATO PLANTS
}

\author{
L. M. Reshotko, S. V. Derevianko, O. O. Dmitruk, I. V. Volkova \\ Institute of Agricultural Microbiology and Agroindustrial Manufacture, NAAS, \\ City of Chernihiv
}

It was found that the additional lighting affects habitus of in vitro plants: red light correction increases the growth of potato cultivars such as Shchedrik, Tyras and Suvenir Chernihivskyi, and blue light correction leads to a significant reduction in height of Suvenir Chernihivskyi potato cultivar and to the accelerated formation of stolons in all tested varieties. The chlorophyll content in the leaves of potato plants was increased with additional lighting. It depended both on the light spectra and the reaction of varieties to lighting.

Key words: in vitro potato plants, plant LEDs, light spectra

Photosynthetically active radiation (380 to $710 \mathrm{~nm}$ ) and physiologically active radiation (300 to $800 \mathrm{~nm}$ ) is important for plant life. Blue, violet (380-490 nm) and red $(600-720 \mathrm{~nm})$ rays directly participate in photosynthesis, stimulate synthesis of proteins and regulate the rate of plant development [1-3].

$$
\text { Blue light, according to }
$$

N. V. Kataieva et al. [4] is the main condition for morphogenesis. Studies of T. N. Konstantinova et. al [5] demonstrated that blue light stimulates setting up of vegetative buds in plants in vitro, and red development of the generative organs. According to W. M. Morgan [6], the light is a prerequisite for adjustment of growth and development of plants in vitro, but high intensity of light is not required. Works of R. A. Karnachuk, V. Yu. Dorofieieva [7; 8] and others show that the light of different spectra regulates growth and development, as well as photosynthetic processes and productivity of potato plants both in vivo, and in vitro.

The source of light during in vitro propagation of potato plants are usually electric lamps of various types, among which the first place is held by fluorescent lamps of LD series (spectral composition: $50 \%$ - violet light $(440 \mathrm{~nm}) 30 \%$ - green light $(500 \mathrm{~nm})$ and $15 \%$ - yellow
(575 nm)). Upon lightning with such lamps, culture of potato plants in vitro have a standard habit - green colour with welldeveloped root system and leaves in the amount not less than $5 \mathrm{U} /$ plant [9].

Under analysis of the available literature sources about the effect of different light spectra on in vitro culture of potato plants it has been detected that first of all investigators were interested in improvement of the standard habit for the purpose of increase of propagation factors of potato microplants $[5 ; 7 ; 8 ; 10-13]$. Set task was implemented by using high-pressure gas discharge lamps (metal halide and sodium) and LED lamps of different emission spectra that are not only energy efficient, but also have significant life cycle. Different response of potato plants to the light was observed, and it depended not only on combination of light rays, but also on variety.

The main objective of our study - to evaluate how various options of plant LED lightning during the last passage affect growth and development of revitalised varieties microplants of potato of varieties Shchedryk, Tyras and Suvenir Chernihivskyi.

Materials and methods. Experiments were conducted under conditions of luminostat. Measurement of chlorophyll a 
and $b$ content in leaves of potato was performed by spectrophotometric method.

Cutting and passage of revitalised plants of potato of in vitro varieties Tyras, Shchedryk and Suvenir Chernihivskyi was performed under sterile conditions, the number of passages - 4, duration - 2025 days at $20-22{ }^{\circ} \mathrm{C}$, photoperiod -16 hours, fluorescent lighting with Philips LD 40 lamps.

To establish the effect of different radiation spectra on plant development in vitro, experiment was performed during the last passage, in which red and blue plant LED strips were used in different variants for additional lighting of microplants (we used the conventional term "correction").

The scheme of the experiment:

Option 1. Control (30 cuttings of the $5^{\text {th }}$ passage of each variety, lighting with fluorescent lamps Philips LD 40);

Option 2. (30 cuttings of the $5^{\text {th }}$ passage of each variety, lighting with fluorescent lamps Philips LD 40, correction with strips with red plant LEDs (640$660 \mathrm{~nm}), 100 \%$;

Option 3. (30 cuttings of the $5^{\text {th }}$ passage of each variety, lighting with fluorescent lamps Philips LD 40, correction with strips with blue plant LEDs (440$450 \mathrm{~nm}), 100 \%$;

Cuttings were cultivated in luminostat for $20-25$ days at $20-22{ }^{\circ} \mathrm{C}$ with 16 hours photoperiod.

Statistical processing of the obtained results obtained was performed using the program Statistica 6.0.

Therefore, it has been established that additional lightning with plant LEDs affects habit of in vitro plants: correction with red light contributes to increase in height of microplants of varieties Shchedryk, Suvenir Chernihivskyi and Tyras, and correction with blue light leads to a significant reduction of height of microplants of variety Suvenir Chernihivskyi and to rapid formation of stolons in all studied varieties. The content of chlorophyll in leaves of potato plants of different varieties increased with additional lightning, but depended both on radiation spectra and on response of variety to lightning. The highest content of chlorophylls for varieties Shchedryk and Suvenir Chernihivskyi has been observed in options corrected with red light, for variety Tyras this parameter is the highest under growing of microplants with correction using red light. 